\title{
Evaluation Of The Magnetic Basement Depth Over Parts Of Bajoga And Environs, Northeastern Nigeria by Stanley's Method.
}

\author{
A.G. Mohammed*.A. Mustapha** \\ *Department of Geology, Gombe State University. Nigeria. \\ **Department of Physics, Bayero University, Kano. Nigeria
}

\begin{abstract}
Four (4) magnetic profiles were established for the evaluation and the magnetic anomaly map, the regional geology and its Residual Magnetic Anomaly helped in identifying the nature and depth of the magnetic sources in the study region. The magnetic residual values range from $-134 n T$ to $+116 n T$. The depth to bed rock from the four profiles taken across profiles $A-A^{\prime}, B-B^{\prime} C-C^{\prime}$ and $D-D^{\prime}$ are $2.40 \mathrm{~km}, 2.23 \mathrm{~km}, 0.90 \mathrm{~km}$ and $1.60 \mathrm{~km}$ respectively. The area shows magnetic closures of various sizes at the Western part of the study area trending Northeast-Southwest and West-East. From the Residual map, Anomalies high are observed at the southern part of the study area reaching a maximum value of +116 nT around Malleri and Dukul villages while Anomalies low were also observed at Northeastern part of the study area reaching a minimum value of -134nT around Bajoga and Bage towns.
\end{abstract}

\section{Introduction}

The study area is bounded by latitudes $\mathrm{N} 11^{\circ} 00^{\prime}-\mathrm{N} 11^{\circ} 30^{\prime}$ and longitudes E10 $30^{\circ}-\mathrm{E} 11^{\circ} 00^{\prime}$ in the Northeastern Nigeria (fig. 1). It has total area of about 1764 Square kilometers with some major towns like Bajoga, Bojude, Wawa; others are Kaisa, Jillahi, Biri Fulani, Guiwa, Malleri, Tongo and Tilde all in Gombe State of Nigeria. The study area is found within the Upper (Northern) Benue Trough which its origin has different school of thoughts. It appears to have developed after Africa came to rest with respect to its hot-spots [1], and the spin axis [2]. Northern part of Gombe have a depth to bed rock of 0.5 to $4.6 \mathrm{~km} \mathrm{[3]} \mathrm{and} \mathrm{studies}$ around Bajoga - Nafada area shows the average magnetic source depths obtained vary between $2.024 \mathrm{~km}$ to $2.616 \mathrm{~km}$ [4] In this respect it may resemble the Michigan and Lower Paleozoic basins of North America that apparently formed when that continent was at rest with respect to underlying mantle by [1]. The total intensity magnetic data (Figure 2) was flown at an elevation of $500 \mathrm{ft}(156 \mathrm{~m})$ above sea level with flight line spacing of $2 \mathrm{~km}$. This is therefore a low resolution data sourced from geological survey of Nigeria (1959). The magnetic anomalies are sourced overwhelmingly from the basement. The main advantage of this data for this study is that cultural features such as railroad tracks, power transmission cables, metals from buildings, drill cores, storage tanks, steel well casings, oil pipelines and other metallic objects are not sources of anomalies in the data and therefore, cultural editing are not required. Large concentrations of cultural sources with particularly strong and pervasive magnetic fields such as cathodically protected pipelines can seriously mask the geologic information contained in aeromagnetic survey data [5].

\section{Material And Method Of Study}

Gridding of the data were done at $1 \mathrm{~km}$ interval along the flight lines which is orthogonal to the regional geologic strike. The grid spacing is tight enough to capture the anomaly details and meet the objective of this study. Experimental work on rock magnetization has made it abundantly clear that contrary to the earlier belief, presence of remnant magnetization is often the rule than the exception, in the rocks of the Earth crust and remnant magnetization associates itself with induced magnetization to orient the polarization vector of the rock mass in some arbitrary direction [6].

The present study will focus on interpretation of Aeromagnetic anomalies over parts of Bajoga town and environs part of Northern Benue Trough using Stanley's method of analysis. This will help in establishing the sedimentary thickness variations and the structural patterns of the study area.

\section{Geology Of The Study Area.}

It is generally accepted by most workers that Benue trough was formed sometimes during the early cretaceous. But there is much speculation with controversy as to its origin. Several theories have been proposed, none has been able to independently explain the microscopic and most tectonic framework of the Benue trough. Early workers believe that Benue Trough is some kind of rift structure however, evidence has been provided lately to suggest the Benue Trough is a strike-slip structure.

Transitional beds (Yolde formation) which grades upwards the marine sequence ranging in age from Turonian-Cenomanian [7]. These transitional beds were followed by the deposition of Lamja and Gombe 
Sandstones. Renewed sedimentation gave rise to Kerri-kerri formation which rest unconformably on the Gombe and Lamja Sandstones and is probably Paleocene in age, followed by lateritic sheet and other superficial accumulation of Riverine Alluvium deposited in the Upper Benue Trough.

The "Y" shape sedimentary basin subdivides the Upper Benue Trough into three Basement exposures, the margin of the Jos Plateau to the West, Adamawa to the South and Hawal massif to the East. The Basement rocks can be subdivided into two major lithologic units. Undifferentiated Migmatites, including high grade Meta-sediment (Amphibolitic Schist, Garnet Micaschist, Quartzite e.t.c) and an Older Granite series containing Orthogneisses and Granites.

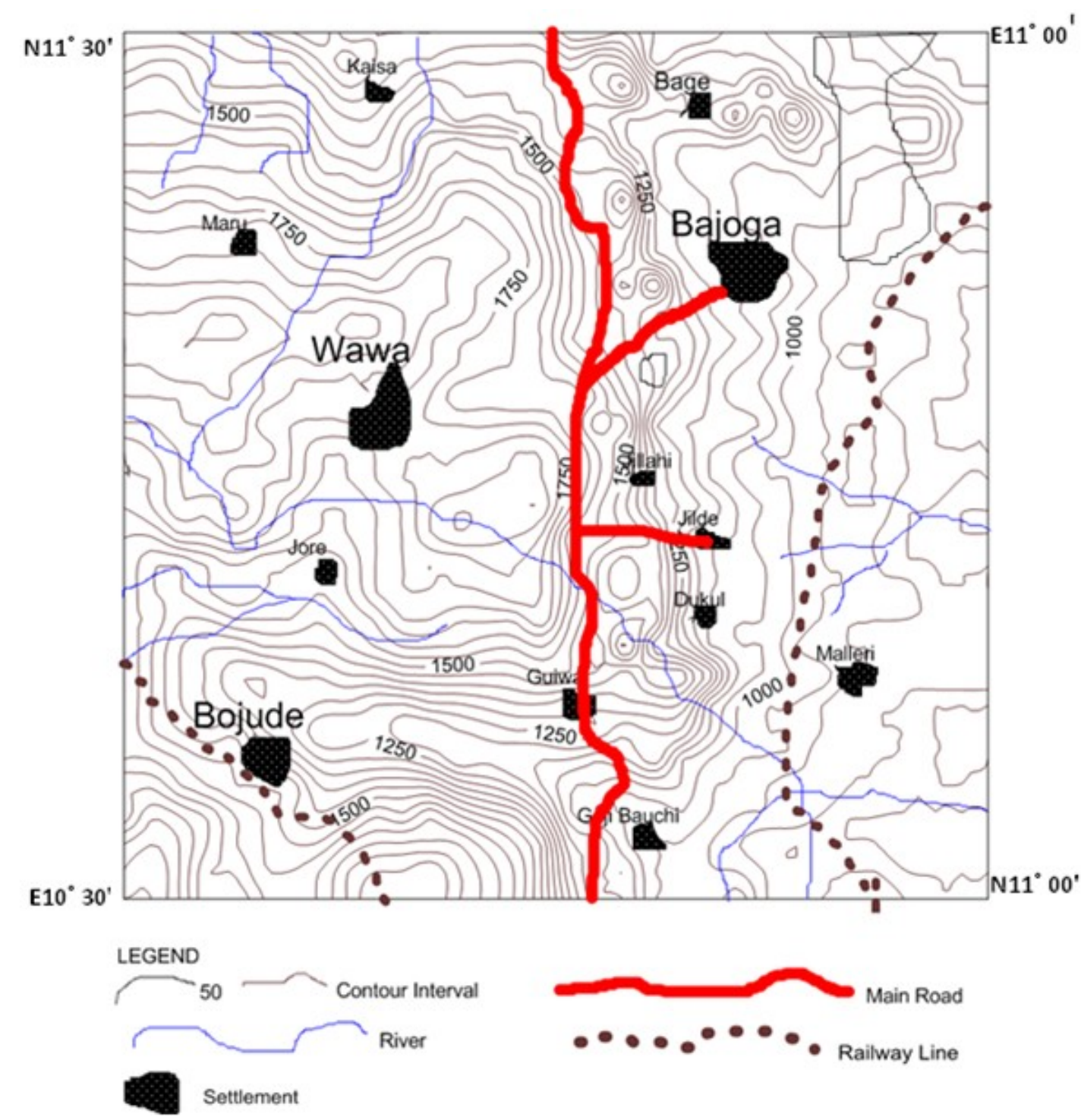

Fig 1: Topographic Map of the Study Area

It is commonly assumed that these units were affected by the Pan African thermotectonic event (600-700 MY). Volcanic rocks are particularly abundant in this part of the Upper Benue Trough with Basaltic lava flow forming characteristic plateau (Biu Longuda) and plugs, especially concentrate at the South and West of the Kaltungo inlier, both lava flow and plugs are post Cretaceous and Miocene age has been assigned to this volcanic activities which is found in some places.

\section{Yolde Formation}

The Yolde Formation, of Cenomanian age, marks the transition between the continental environment and the major Turonian transgression. It consists of a variable sequence of thinly bedded sandstones, sandy mudstone and Shelly limestone. The Formation overlies the Bima sandstone in both Gombe and Numan-Muri areas but absent around Fika. A type section was designated in the Yolde stream in the Western part of the Yola arm. The Feldsperthic Yolde Sandstone contains siliceous cements in contrast to the poorly consolidated 
Sandstones elsewhere. The lower Sandstone, mudstone portion of the Yolde Formation is interpreted to be of alluvial origin. The upper part has more thinly and regularly bedded bioturbated Sandstone and low diversity bivalve faunas.

\section{Data And Methodology}

The total magnetic field over the study area was obtained by digitizing one Aeromagnetic map of Geological Survey of Nigeria (GSN) airborne geophysical series sheet: 131 (Bajoga). The map was digitized using grids of 2 by 2 square kilometers. The data obtained by digitization of the various maps are equally spaced, which is good in minimizing aliasing affecting in sampled data. [8]. A grid interval of $2 \mathrm{~km}$ was used to obtain 32 by 32 data points. The gridded data were then integrated and used to plot the total magnetic intensity map of the study area (fig. 2).

\section{Separation Of Aeromagnetic Data Magnetic Modelling and Depth Determination}

For resource exploration purposes one of the most useful inferences that may be derived from analyses of potential field (magnetic and gravity) data is the depth to crystalline basement beneath sedimentary cover [9]. Most magnetic anomalies come from only a few rock types, such as volcanics, intrusives and basement rocks. Magnetic data therefore can be used to estimate depth to basement, a classic use for such data [10]. Generally, there are two approaches to potential field modeling: inverse and forward modeling. In magnetic modeling the inverse approach is whereby a $2 \mathrm{D}$ or $3 \mathrm{D}$ susceptibility or geometric model is computed to satisfy (invert) a given observed magnetic field. In this case, the input is the observed data while the output is the geologic model. That is, the observed data is used to draw conclusion about the physical properties of the system. Physics principle allows the means for computing the data values given a geological model. This implies that if one has the knowledge of the properties of a system one can predict the response of that system. Therefore, the input of a forward model is the geologic model while the output is the computed values. The analytic signal is independent of magnetization direction and the direction of the earth's magnetic field [11]

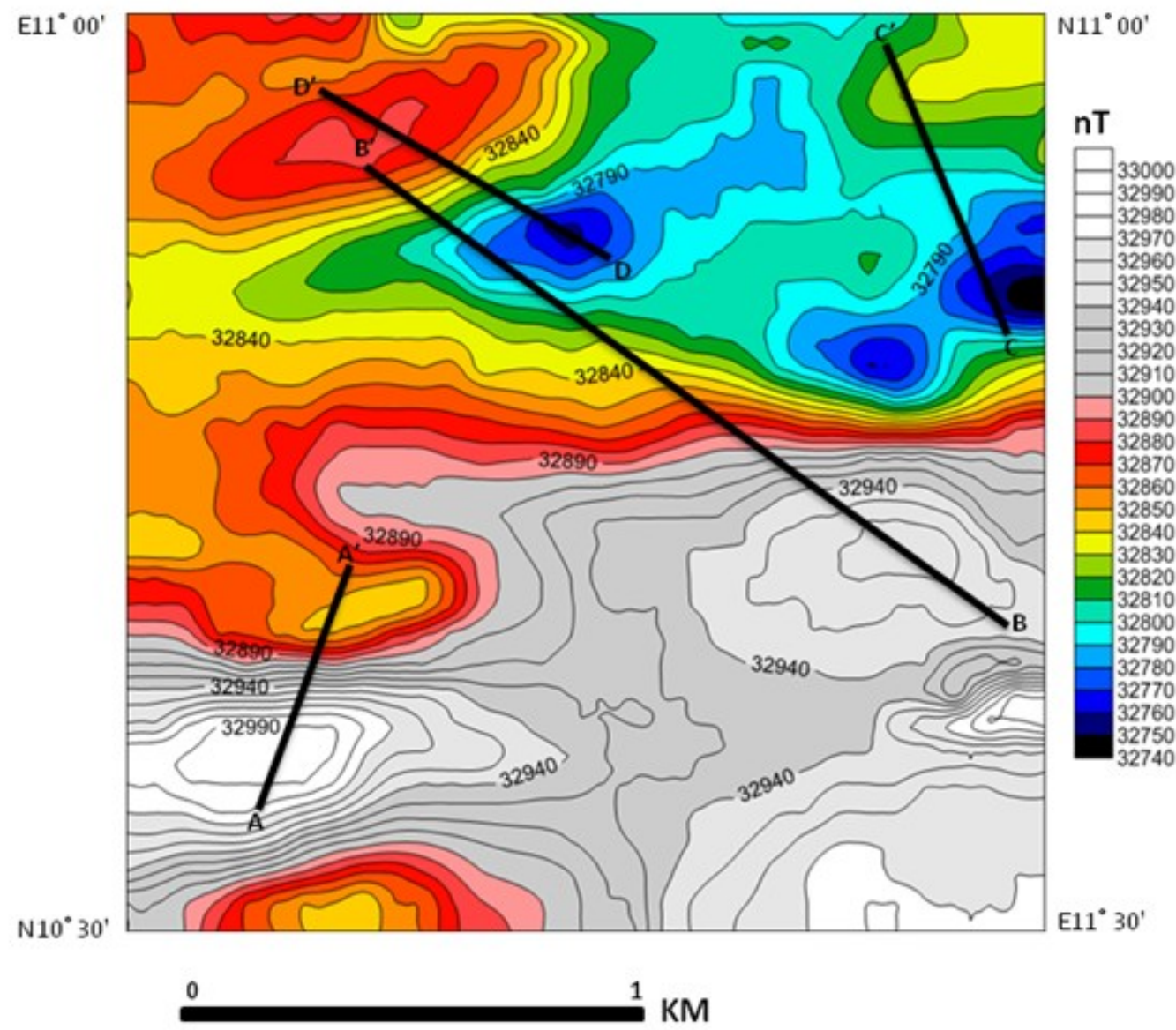

Fig 2a: Total Magnetic Intensity of the Study Area. 


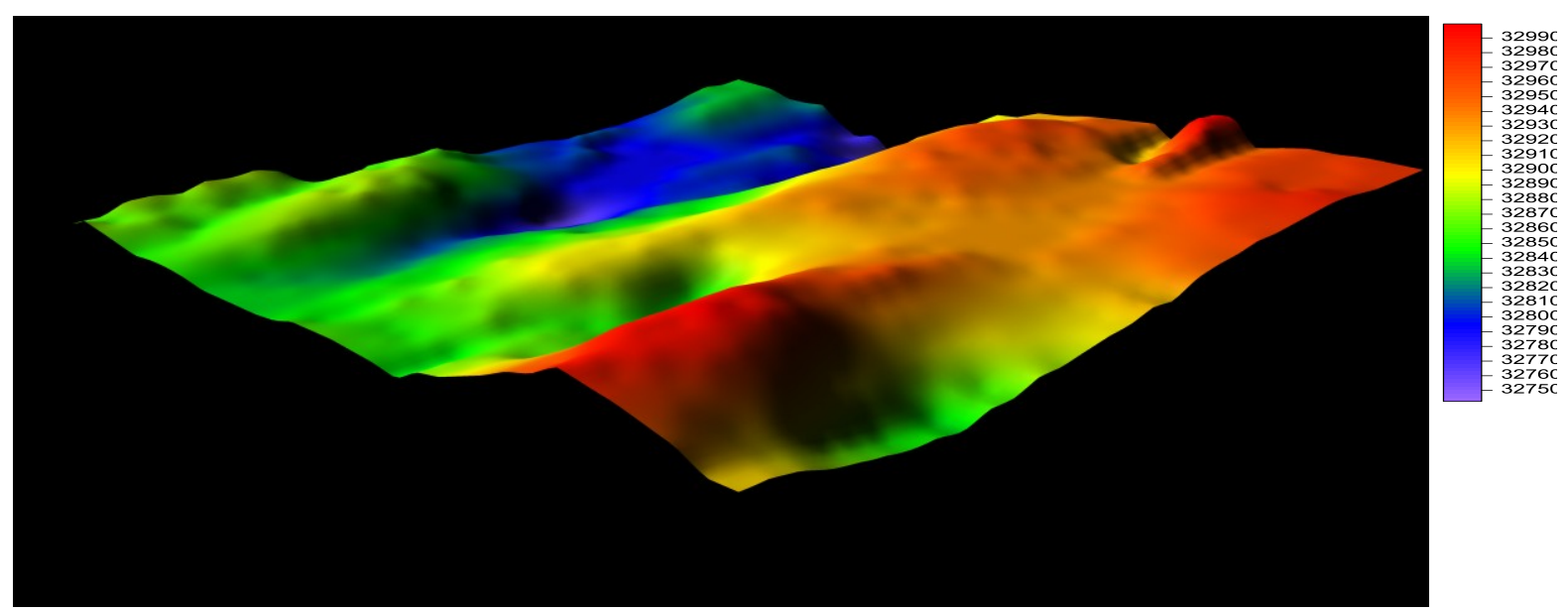

Fig 2b: 3-D Surface Map of the Study Area.

\section{Magnetic Anomaly Enhancement}

In order to examine basement influence on the sedimentary section in the study area we also performed basement structural analyses using transformed magnetic anomaly data to show deformation patterns and structural architecture of the basement. Enhancements of magnetic anomaly data accentuate the internal structure and edges of magnetic sources. The most important and accurate information provided by magnetic data is structural fabric of the basement. Major basement structures can be interpreted from consistent discontinuities and /or pattern breaks in magnetic fabric [12]. The basement structures manifest as shear zones, fault (brittle faults and domain fault boundaries) which are usually weak zones. These basement structural features are lineaments and in most cases subtle. Subtle potential field lineaments could be gradient zones, alignment of separate local anomalies of various types and shapes, aligned breaks or discontinuities on the anomaly pattern.

Subtlety of desirable lineament requires detail processing using a wide range of anomaly enhancement technique and display parameters [13]. Filtering and image processing of aeromagnetic data are essential tools in mineral exploration. Directional horizontal derivatives enhance edges while vertical derivative narrows the width of anomalies and so locate the source bodies more accurately [14].

The residual anomalies delineate a belt of four conspicuous magnetic lows in the northeastern part of the study area. These anomalies are approximately centered at Bajoga and Bage towns with a minimum value of $-134 \mathrm{nT}$ and Southeast and Southwestern part of the study area centered around Bojude and Malleri with a maximum value of $+116 \mathrm{nT}$. On the basis of available geological information, [3] interpreted the sources of the magnetic low anomalies at Bajoga and Nafada as corresponding to the sedimentary sub-basins while the areas with high magnetic anomalies are possibly due to uplift of the Precambrian bedrock or to intrusions of volcanic rocks (Rhyolites). The plot of six profile lines cross the study area namely A-A', B-B', C-C', and D-D', taken across the areas of magnetic low/high anomalies reveal variability in the source of the anomaly (fig. 3). Profile A-A' with a length of about $0.7 \mathrm{~km}$, the observed anomaly curve represents a magnetic high of $+110 \mathrm{nT}$ suggesting the presence of high magnetic sediments and the depth to bed rock is about $2.40 \mathrm{~km}$. Profile B-B' has a length of about $3 \mathrm{~km}$, the residual anomaly curve associated with this profile is characterized by high magnetic anomaly of approximately $+110 \mathrm{nT}$ which was interpreted due intrusions of volcanic rocks (Rhyolites) reaching a maximum at the centre of the profile and the depth to bed rock is approximately $3.23 \mathrm{~km}$. Profile C-C' has an approximate length of $0.8 \mathrm{~km}$, the observed anomaly curve also presents a magnetic high value of $+80 \mathrm{nT}$ suggesting the presence of high magnetic materials with an approximate depth of $0.90 \mathrm{~km}$. Profile D-D' has a length of about $0.7 \mathrm{~km}$; the observed profile curve presents a low magnetic anomaly of about -130nT Suggesting the presence of sedimentary cover having an approximate depth to bed rock of $1.60 \mathrm{~km}$.

\section{Gologic Modeling}

Thus, there is spatial relationship between paleotopographic highs on the Precambrian basement, structural and thickness anomalies in the overlying Tertiary sediments. Thus, the depth to magnetic basement map (Figure 4) has located deep depocenters, high blocks, sedimentary fairways and basement flanks in the study area.

The eventual magnetic data were presented as magnetic profiles by plotting the magnetic values against station separations for each traverse. Magnetic contour map (2D plot) and surface map (3D plot) of Analytic Signal Amplitude were also constructed for more qualitative interpretation using Surfer 9 software. 
The results obtained from the digitizing magnetic map of the study area were presented in a qualitative and quantitative interpretation which involves the analysis of the basement topography with the magnetic contour and surface maps, magnetic profiles, and estimation of the depth to the top of the magnetic basement respectively.

The Residual magnetic contour map obtained from the analytic signal amplitude enhanced data generated from the magnetic values for the study area is as shown in Figure $3 \mathrm{a}$ and $3 \mathrm{~b}$. The map shows the areas of magnetic lows and magnetic highs analyzed with color variations: $-140 \mathrm{nT}$ to $-40 \mathrm{nT}$ (Deep Blue), $-39 \mathrm{nT}$ to $+30 \mathrm{nT}$ (Ash) and between $31 \mathrm{nT}$ to $130 \mathrm{nT}$ (Red) respectively. The low magnetic distribution is observable at the Northeastern part (deeper fracture or faulted zone) of the study area trending Northeast-Southwest with prominence at the center (deepest fracture or fault zone).

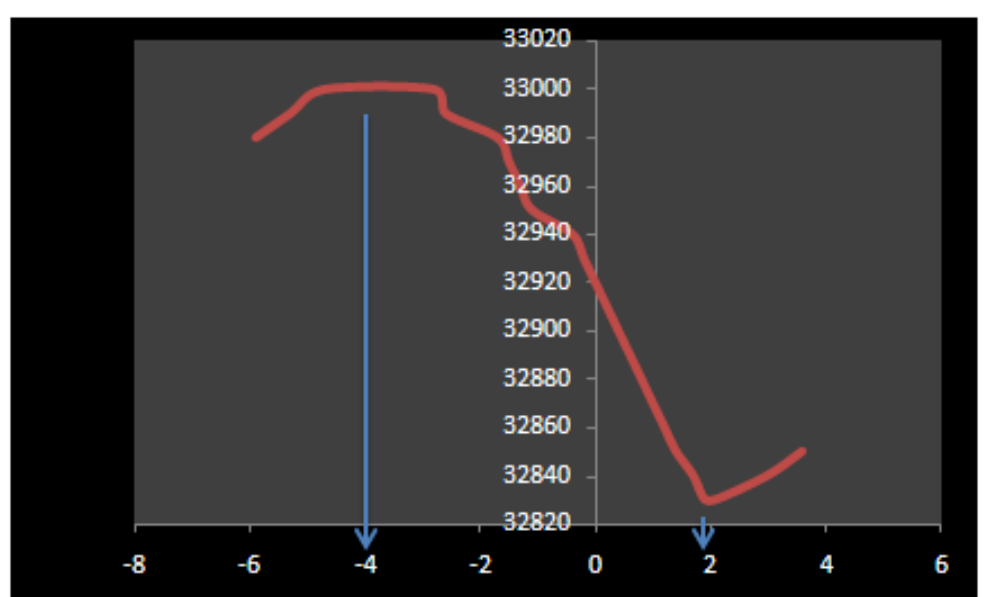

Fig 3a: Aeromagnetic Profile A-A’ using Stanley (1977) Dyke Method

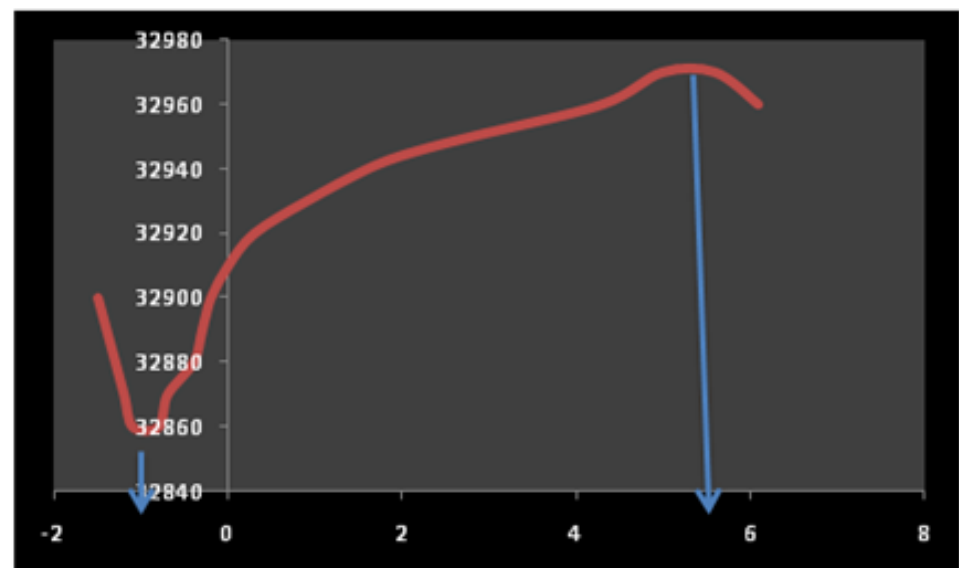

Fig 3b: Aeromagnetic Profile B-B’ using Stanley (1977) Dyke Method

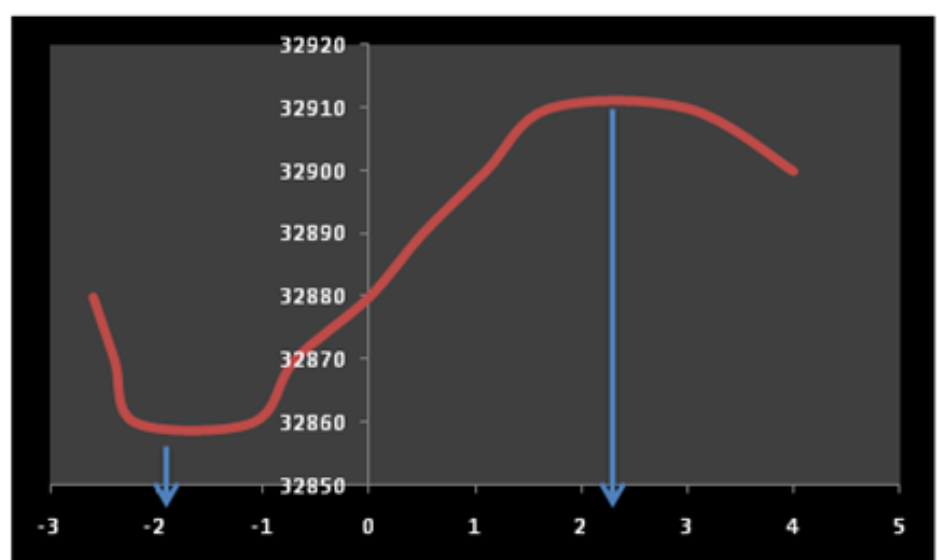

Fig 3c: Aeromagnetic Profile C-C' using Stanley (1977) Dyke Method 


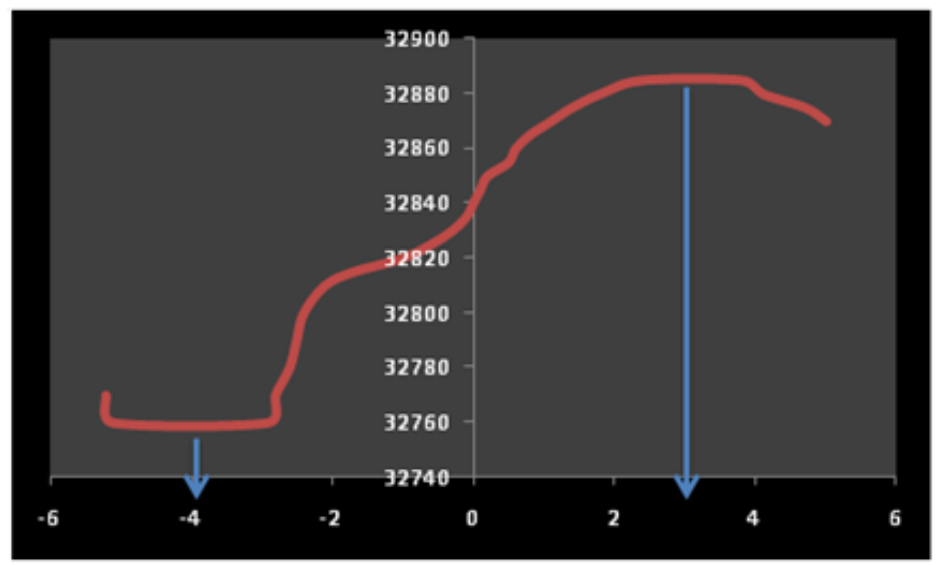

Fig 3d: Aeromagnetic Profile D-D’ using Stanley (1977) Dyke Method

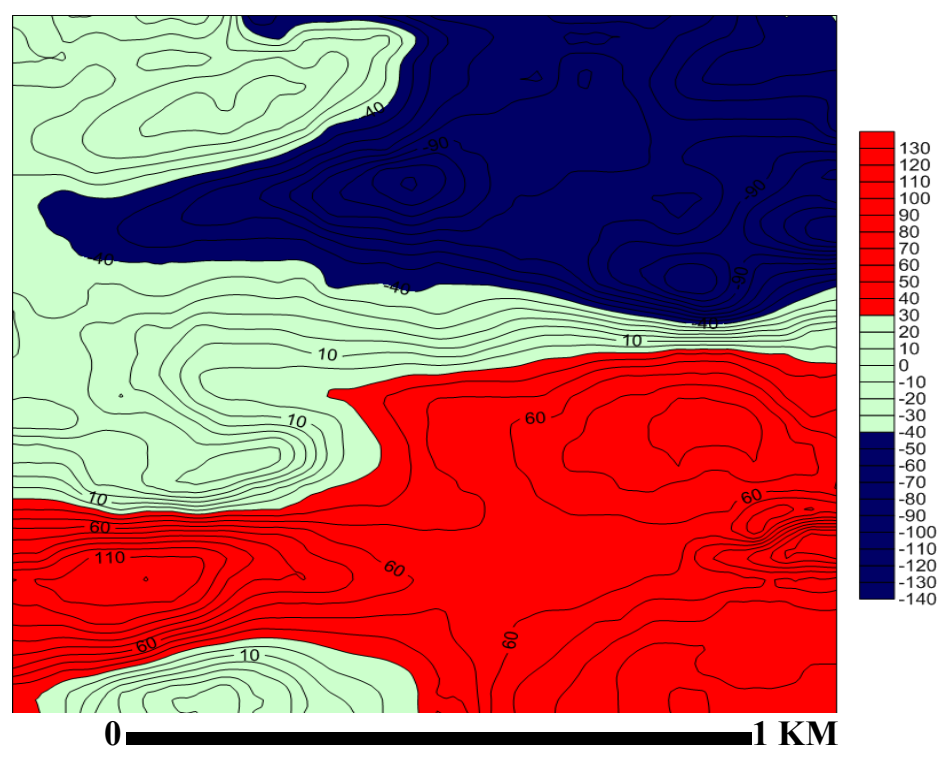

Fig 4a: Residual Magnetic Anomaly of the Study Area

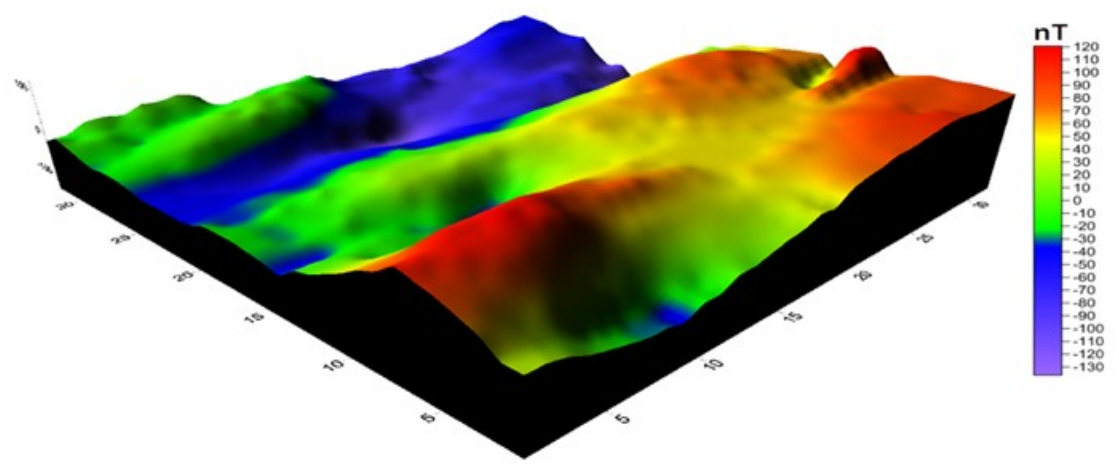

Fig 4b: Surface Map of Residual Anomaly of the Study Area.

\section{Summary And Conclusion}

The magnetic residual values range from $-134 \mathrm{nT}$ to $+116 \mathrm{nT}$. The area shows magnetic closures of various sizes at the Western part of the study area trending Northeast-Southwest and West-East. From the Residual map, Anomalies high are observed at the southern part of the study area reaching a maximum value of $+116 \mathrm{nT}$ around Malleri and Dukul villages while Anomalies low were also observed at Northeastern part of the study area reaching a minimum value of $-134 \mathrm{nT}$ around Bajoga and Bage towns. The depth to bed rock calculated ranges from 0.9 to $2.40 \mathrm{~km}, 2.4 \mathrm{~km}$ as in profile A-A, $2.23 \mathrm{~km}$ as in profile $\mathrm{B}-\mathrm{B}, 0.9 \mathrm{~km}$ as in profile C- 
$\mathrm{C}^{\prime}$ and $1.6 \mathrm{~km}$ as in profile D-D which is in conformity with earlier works done Nur et al in 1994 as $2.02 \mathrm{~km}$ to $2.61 \mathrm{~km}$ and by Ofoegbu in 1998 as $0.5 \mathrm{~km}$ to $4.6 \mathrm{~km}$.

\section{References}

[1]. Burke, K. C. and Dewey, J. F. Nature, G. N (1974), 249, pp 313-336.

[2]. Burke K. C. (1976); Tectonophysics, 36. Pp192-206

[3]. Ofoegbu, (1985): A review of the geology of the Benue Trough of Nigeria. Journal of African Sciences. Vol 3 pp $285-291$.

[4]. Nur, A; Ofoegbu, C. O and Onuoha, K. M. (2003). Spectral Analysis and Hilbert transformation of Aeromagneticdata over the Benue trough, Nigeria. Global Journal of geological SciencesVol1 (2), 129-142

[5]. Ajakaiye D. E. (1981): Geophysical inverstigation of Benue Trough; A review. EarthSci; pp 126-136

[6]. Osazuwa I. B. Ajakaiye, D. E. and Verheijen P. J. (1981): Analysis of the structure of parts of Upper Benue riftvalley on the basis of new geophysical data. Earth evolution Sci. 2. Pp 233-236.

[7]. Osazuwa, I. B; Ajakakaiye, D. E. and Verheijen, R. J. (1981). Analysis of Structure of part of Benue Valley on the basis of new geophysical data. Earth Evolution Science. 1: 126-135

[8]. Onwuemesi, A. G. (1996): One-dimensional spectral analysis of aeromagnetic anomalies and curie depth isothermal in Anambra basin of Nigeria: Geodynamics Vol 23 No2. Pp 95-107.

[9]. Udensi E. E. (2000). Interpretation of Total Magnetic Field over the Nupe Basin and the surrounding Basement Complex using Aeromagnetic Data. Unpublished PhD. Thesis submitted to Ahmadu Bello University Zaria.

[10]. Milligan, P. R., Reed, G., Meixner, T., \& FitzGerald, D. (2004). Towards automated mapping of depth to basement using new extensions to an old method, Australian Society of Exploration Geophysicists 17th Geophysical conference and Exhibition, Sydney.

[11]. Keary, P. and Brooks, M. (2002). An in introduction to geophysics exploration. Blackwell Science Ltd. Oxford $3{ }^{\text {rd }}$ Ed. Pp 255.

[12]. Li, J., \& Morozov, I. B. (2007). Geophysical structural patterns of the crystalline basement of the EasternWCSB. Canadian Society of Geophysicists Convention, 672-675

[13]. Telford, W. M.; Geldart I. P, Sherrif, R. E and Keys, D. A. (1976). Applied Geophysics. Cambridge University Press, Cambridge.

[14]. Spector A. and Parker W. (1979): Computer Compilation and interpretation of geophysical data in geophysical and Geochemistry in search of Metallic Ores. P. J. Hood, Ed., Geol. SW-V. Can. Econ. Geol. Rep. 31, pp 527-544.

[15]. Li, J., \& Morozov, I. (2006). 3D Aeromagnetic mapping of the Williston basin basement, 2006 CSPG-CSEGCWLS Convention, pp. 65-68.

[16]. Lyatsky, H. V., Friedman, G. M., \& Lyatsky, V. B. (1999). Principles of practical tectonic analysis of cratonicregions in Lecture notes in Earth Sciences, Springer-Verlag, 84.

[17]. Lyatsky, H. V., Pana, D. I., \& Grobe, M. (2005). Basement structure in Central and Southern Alberta: Insights from Gravity and Magnetic maps, Alberta Energy and Utility Board/Alberta Geological Survey (EUB/AGS) special report72, 83p.

[18]. Gibson, R. I. (1998a). Magnetic frequency-depth relationship: Geologic applications of Gravity and

[19]. Gibson, R. I. (1998b). Magnetic susceptibility contrast versus structure: Geologic applications of Gravityand Magnetic: case Histories. In I. Gibson., \& P. S. Millegan. (Eds.). SEG Geophysical Reference No.8 and AAPG Studies in Geology (No. 43, pp. 7981). Tulsa, United States.(50) Carter et al., 1963 and Guiraud, 1990 Zaborski et al., (1997)

[20]. (Maurine et al., 1986; Zaborski et al., 1997; Obaje et al., 1999)

[21]. Obaje et al., 1999)

[22]. Philips, S. \& Reynolds, 1998)

[23]. (Milligan, Reed, Meixner, \& FitzGerald, 2004Kogbe, 1976; Carter et al, 1963)

[24]. Gibson, 1998a

[25]. Peters, L. J., 1949, The direct approach to magnetic interpretation and its practical application: Geophysics, 14, 290-320.

[26]. Li, Y., and D. W. Oldenburg, 1996, 3-D inversion of magnetic data: Geophysics, 61, 394-408

[27]. Badmus B. S., Olatinsu O. B., Journal of Physical Sciences 4(10) (2009) 592-606.

[28]. Ajakaye, D. E. (1980). Geophysical Investigation in the Benue Trough. A review, Earth Evolution,

[29]. arbitrary shape. In Parks, G. A. Editor. Computers in the mIneral Industries, part 1: Stanford University Publication geological Sciences, 9; 646-480

[30]. Ajayi, T. R. (1981). Ground Magnetic Studies of Ilesa East Southwestern Nigeria. African Journal of Environmental Science \& Technology. Vol 4(3) pp 122-131.

[31]. Bhaattacharya, B. K. (1960). Magnetic Anomalies due to Prism-shaped bodies with arbitrary polarization, Geophysics, $29: 517-531$.

[32]. Elueze, A. A. (1986). Vertical components of Ground Magnetic Studies of Ilesa Area. Southwestern Nigeria. Geological survey Nigeria.

[33]. Folami, S. L. (1992). Interpretation of Aeromagnetic data in Iwaraja Area, Southwestern Nigeria. Journal of Mining Geology. 28(2). Pp 391-396.

[34]. Ojo, S. B. (1990). Origin of a Major Magnetic Anomaly in the Middle Niger Basin, Nigeria.

[35]. Sherrif, R. E. (1978). A first course in geophysical exploration and interpretation. IHRDC Publication, Boston.

[36]. Talwani, M. (1965).computation with the help of digital computer of magnetic anomalies caused by bodies of arbitrary shape. Geophysics, 30: 797-817.

[37]. Weymouth, J. W. (1985) Geophysical Surveying of Archeological sites surveying. Archeological Geology, Yale University Press. New Haven and London. Pp 191-235. 